\title{
Increasing Skills of Inclusive Elementary Classroom Teachers in Handling Children with Learning Disabilities
}

\author{
Sari Rudiyati ${ }^{1}$, Mumpuniarti ${ }^{1} \&$ Pujaningsih ${ }^{1}$ \\ ${ }^{1}$ Special Educational Department, Faculty of Education, Yogyakarta State University, Yogyakarta, Indonesia \\ Correspondence: Sari Rudiyati, Special Educational Department, Faculty of Education, Yogyakarta State \\ University, Yogyakarta, Indonesia. Tel: 62-8121-571-738. E-mail: sari_rudiati@uny.ac.id
}

Received: August 1, 2018

doi:10.5539/ass.v14n11p90
Accepted: September 1, $2018 \quad$ Online Published: October 22, 2018

URL: https://doi.org/10.5539/ass.v14n11p90

\begin{abstract}
The general purpose of the research is to make a handling model of the children with learning disabilities based on teaching accommodations and modification collaborating with researchers from Chiang Mai University, Thailand. The specific purposes of the research are: 1) Dissemination and implementation Model of Learning Accomodation and Modification for students with Learning Disabilities 2) To increase skills of the inclusive elementary classroom teachers in handling the children with learning disabilities. The research is a part of research development of handling the children with learning disabilities model based on teaching accommodations and modification which adapted from a development model by Borg and Gall (2003). Subject of research: teachers and students in elementary schools in Yogyakarta Special Province, Prembun Central Java, Ngawi East Java, Indonesia. Data collection techniques had done by tests, questioners, observations, interviews, documentations. Data Analysis had done by description analysis. The research's finding can be presented as follows: The third year research had done dissemination and implementation through socialization, training, workshop and mentoring: (1) Handling children with learning disabilities is still not implemented adequately; (2) Perceptions and expectations of teachers to the problems of handling children with learning disabilities tends to be negative, hence the need for guidelines on the application of teaching accommodation and modification for children with learning disabilities; (3) the skills of inclusive elementary classroom teachers on handling the children with learning disabilities had increased through socialization, training, workshop and mentoring.
\end{abstract}

Keywords: increasing skills, elementary classroom teachers, handling children with learning disabilities

\section{Introduction}

Talking about handling children with learning disabilities, there are some similarities between Thailand and Indonesia. Those are: a) Children with specific learning difficulty or children with learning disabilities are difficult to recognize because physically they are same with another children. The differences are their profiles that are slow in learning, underachieving, difficult to learn. b) There are so many misjudgments by teachers towards children with learning disability. In result, their potency is hidden and has never been expressed. c) A proper handling will affect those children to foster their own potency. On that count, this research collaboration is a concept to solve those problems.

The research has some importance to make a network in order to solve problems faced by Indonesia and Thailand and seek for solution of handling children with learning disabilities at school. In a short term, the quality of handling children with learning disabilities will be higher in Indonesia and Thailand. In a long term, the improvement of the quality of education in Indonesia and Thailand will be able to continue through other bilateral corporation.

There are three importances of the research related to problems about handling children with learning disabilities. First, Teacher Preparation Program does not give any material about children with learning disabilities. It makes almost all of regular teachers are difficult to handle the children with learning disabilities. Then, the level of acceptance of teachers also affects their way to treat the children with learning disabilities. Unfortunately, the acceptance of teachers is very rare (Bryan, 1997; Sale \& Carey, 1995 on Pavri \& Lutfig; Cook, 2000) so it is no wonder if a negative judgment concentrated to the children with learning disabilities. Lopes et al. (2004) agreed with the statements. They said that regular teachers are difficult to handle children with learning disabilities and feel that the children with learning disabilities are burden for them. The children with learning disabilities need 
more time and attention to learn compared to other children but they are underachiever. A research of Sari Rudiyati, et al. (2009) about learning model of accommodation to handle children with specific learning disability in various classes is still difficult to apply because the low percentage of the acceptance of teachers towards children with learning disabilities. The low percentage of teachers also happens in inclusive school (Ernawati, 2012).

Second, there is bad impact caused by neglecting children's needs. Litch (Smith, 1998) said that wrong adaptation is the cause of failure faced by children with learning disabilities. Then, they are difficult to socialize and rejected by their friends (Farmer kin, 1996; Nabasoku \& Smith, 1993 on Pavri \& Lutfig, 2000). Lackaye and Margalit (2006) found that children with learning disabilities feel lonely and bad emotion. The feeling can be developed to depression (Magg \& Reid, 2006) and tendency to commit suicide. When teacher give a bad example to neglect student with learning disabilities, another students will imitate the teacher's attitude. Favazza et al. (2000) explained that the rejection towards children with learning disabilities happens in unsupported places to do rejection. Kim (2011) clarified that the existence of teachers is important to make a better situation that can encourage children with learning disabilities to interact with another children.

Third, the main focus of the research is the existence of teachers as the main actor to establish situation of the class. Teachers expected to accept the children with learning disabilities and to develop strategy which is suitable for children needs. It will be the foundation of developing model of teaching accommodation and modification. The model aims to educate teachers how to treat student with learning disabilities without being unaware with another students.

Handling model of children with learning disabilities based on teaching accommodation and modification compiled in previous research needs to perfect because it focused only on general children with learning disabilities. Hopefully, this research can perfect previous research by focused on children with learning disabilities. It will be a guide-book which contains various alternatives to accommodate and modify the teaching activity with clear applying steps.

\subsection{Literature Review}

\subsubsection{Children with Learning Disabilities}

Learning disability is an English term to refer difficulties to learn. In Indonesian language, there is a misconception of translating the term. Children with special disability actually have potential to make a high achievement in learning if they get a right service of learning. Specific learning disability is a multi-disciplinary concept applied in education science field, psychology and also medical science.

Hallahan, Kauffman and Lyod (2002), gives a definition of specific learning difficulty or learning disabilities as follows:

Specific learning disability is a disorder in one or more than one basic psychological process about understanding and using utterance or sign. It can be a disability to hear, think, speak, write, spell, or count. The limitation is in some condition like perceptual disorder, brain damage, dyslexia, and aphasia. It is not included for children having learning problems caused by visual disorder, hearing disorder, emotional problems, poverty, environment, culture and economy.

From those definition stated above, we can affirm that there are some aspects that can explain about specific learning disability or learning disabilities: (1) Mismatch between potential and achievement. In the case of specific learning difficulty, mismatch of potential and achievement is being a reference based on some definitions which stated by experts. Achievement here refers to recent academic competence which can be known from the learning result in some lessons (reading, mathematics, writing, and so on). As explained from some definitions, specific learning disability is manifested especially in some aspects related with academic things such as reading, writing, mathematics and so on. While potential refers to intellectual competence measured by intelligence test. Someone with specific learning difficulty usually has problem with academic achievement, especially in certain subjects, which actually has an average intelligence or even more superior than people in his age. It is caused by external factor directly. (2) Minimal Disorder of Brain. Although only a few definitions have discussed about this, some definition stated that specific learning difficulty occurs by some problems in the process of understanding or stimulus processing. It means that there is a difference between someone with specific learning difficulty or learning disabilities and normal learner in term of stimulus processing in brain. (3) Fundamental Psychology Process. Specific learning difficulty is caused by problems in receiving and processing process of stimulus. If it is related with the understanding of learning, there are some problems in one or more process in attention, sensation, perception, information processing, information storing 
and information calling process. All those process are fundamental psychology process.

\subsubsection{Teaching Accomodation and Modification}

Accommodation is an adaptation of curriculum and test which enable students to perform what they know without changing content or criteria of learning achievement from learning objective. Particularly, teacher or school can change the way of service or the atmosphere of material delivery so that the student can respond. However, learning objective and test form are not included in the change. Torey (2004) explained about the accommodation coverage which applied in the process of teaching and learning. There are some coverages of accommodation and modification as follows: (1) Material and way of teaching; (2) Assignment and assessment in the class; (3) Time demand and scheduling; (4) Area of learning; (5) Use of special communication system

Children with learning disabilities can communicate with surroundings through language with no special specification so that the use of special language is not discussed in this research. Yuen, Westwood \& Wong (2004) explained the accommodation given by teacher in 3 parts; learning strategy, empower external group and curriculum adaptation. The difference found in learning strategy and curriculum adaptation is time requirement in preparation held by teacher. A specific learning strategy can be done with no special preparation. Meanwhile, curriculum accommodation needs more preparation. This research focuses on general accommodations that are: (1) material accommodation, (2) Assignment and assessment, (3) Time demand, (4) Learning area. The implementation of the accommodations held by teacher or by empowering external group (experts and parents).

Teaching modification is a change in what is expected learnt by the students. It is made to give more opportunities to participate meaningfully and productively along with other students in the class and in the school environment. Teaching modification comprises some changes: (1) Learning level, learning level is adapted to student level of competence so that student can get different material, i. g. student learns mathematics at the level below the class graded where now he belongs to (on the basis of the assessment result based curriculum); (2) Content/curriculum, student learns material which quantitatively is much less (material achievement is less, a simpler learning process), i. g. Learning material learnt in one time is much less with an addition of practicum activity and worksheet. Reduction of material content is adjusted to the competence level of student obtained from assessment result based curriculum; (3) Learning result criteria, student have special learning objective from IEP based on assessment of team so that the same minimal ability criteria for different target achievement is possible. i. g. student share expected to be able to place in order national flag based on its color in worksheet, while learning objective in the class is actually matching national flag with country name; (4) Evaluation format, i. g. a use of simpler task (fewer number of option in multiple choice/two option from four answer option, give a keyword or picture help to answer question), the use of multiple choice to replace essay question, given test preview for learning guide.

According to those 4 things above, student get modification and get reduction in the number of task and complexity of task given. This research focuses on the modification coverage explained before.

1.1.3 Handling Model of Children with Learning Disabilities based on Teaching Accommodation and Modification

Model design of children with learning difficulties handling based on accommodation and modification had developed from previous model obtained from Pujaningsih (2007) and continued research by Rudiyati et al. (2010-2012). The previous model is a general guideline which has not pointed at children with learning difficulties and specifically to teaching accommodation and modification. This model contains flexibilities in 4 aspects: a) Material giving and way of teaching, b) Task giving and assessment, c) Time demand and scheduling, d) Learning area. Visualization of previous model can be shown in this table below:

\section{Preparation}

Objective: Creating a conducive academic condition toward diversity of student

Assessment of learning needs of student with learning disabilities

Target:
a. Teacher see difference as a positive thing
b. Classmate want to accept diversity of children with learning disabilities and want to help other student with some other problems
c. Learning needs of student with learning disabilities is identified 


\section{Teaching Accommodation and Modification Material}

general: decision and implementation plan of teaching accommodation and modification for children with learning disabilities

\section{Implementation}

\section{- Collaboration between classroom teacher and or inter-disciplinary teacher with special teacher} - Implementation continuously

Figure 1. Handling model of children with learning disabilities based on teaching accommodation (Rudiyati et al. 2011)

\subsection{Objective}

The general objective of the research is to make a handling model of teaching accommodations and modification for children with learning disabilities collaborating with researchers from Chiang Mai University, Thailand. The specific objectives of the research are: 1) Dissemination and implementation Model of Teaching Accommodation and Modification for students with Learning Disabilities 2) To increase skills of the inclusive elementary classroom teachers in handling children with learning disabilities.

\section{Methodology}

The research is a part of research development of teaching accommodation and modification for children with learning disabilities in elementary schools which adapted from a development model by Borg and Gall (2003). Subject of research: teachers and students in elementary schools in Yogyakarta Special Province, Prembun Central Java, Ngawi East Java, Indonesia. Data collection techniques had done by test, questioners, observations, interviews, and documentations. Data Analysis had done by description analysis.

\section{Results}

Target the third year of research: dissemination and implementation. In the third year implemented and disseminated that requires several steps of activities as follows:

\subsection{Socialization}

Socialization of the application of model and guide book teaching accommodation and modification for children with learning disabilities in the Educational Office and elementary schools in the Special Region of Yogyakarta, the Central of Java Province and the East of Java Province. The results of the socialization included that both of the Head of Educational Office and the Principals of Inclusive Elementary Schools were very supportive of the dissemination and implementation activities of teaching accommodation implementation model for children with learning disabilities

The socialization about implementation of teaching accommodation and modification for children with learning disabilities had done in three provinces that were in Yogyakarta Special Province on June 17, Centre of Java Province on July 26 and East of Java Province on August 5, 2017:

\subsubsection{Identifying Knowledge, Response and Skill of Teacher in Handling Children with Learning Disabilities}

Based on the result of questionnaire and observations that the teacher's answer and shown that most of teachers of inclusive elementary school still less of knowledge, acceptance response and skill to handle children with learning with disabilities.

The elementary classroom teacher's knowledge of the learning problems in children with learning disabilities have shown that: (1) children with learning disabilities often interfere with the learning process in the classroom They like to disturb his friends and behaving aggressively; (2) If given a task, children with learning disabilities was unable to complete the task completely, in accordance with a predetermined time, and when given the task, not directly done, but see another friend who used to work being done; (3) The learning achievement of children with learning disabilities have low ability, below the average of a group of students in the class; (4) Results of study children with learning disabilities in mismatch with the efforts being made (5) children with learning disabilities attention quickly move or rapidly changing and showing deviant behavior; such like seclusion, withdrawn, and less able to interact with the environment; (6) less enterprising, if given the task not do or avoid; (7) children with learning disabilities often late or absent from school without a reason and there is no desire to learn or lazy to learn; (8) children with learning disabilities is not capable of reading, spelling, writing, or arithmetic.

Based on interviews, observations and study the documentation, and also discussed result with Researchers Team 
from Chiang Mai University that educational background does not provide provisions of children with learning disabilities caused almost all regular teachers in primary schools face problems in handling children with learning disabilities. Some sources also suggest the same thing, namely that the regular teachers feel a lot of the burden when dealing with children with learning difficulties who require time and attention more than other friends and did not show results as expected. Low teacher expectations of many addressed to children with learning disabilities. This is related to acceptance of teachers of children with learning difficulties who are still rarely found in this study. Praise rarely done by teachers, also the refusal actively, often addressed to children with learning disabilities compared with children without learning difficulties. Whereas the teachers expectations have an important position in encouraging, developing, maintaining or changing student behavior. A teacher's expectation affect the treatment of teachers to children with learning disabilities and directly or indirectly, also affect the child's development, and the effect on learning outcomes in the classroom.

Teachers' expectations are also associated with the interaction of the teacher and the child, while it is an important component in the implementation of teaching accommodation and modification. Therefore the teacher's expectation at children with learning disabilities needs to be changed first to be positive before applying the learning accommodation and modification. Some behaviors associated with teachers' expectations are still negative towards children with learning disabilities consisting of:

a. Teacher has not been a lot of smiles, nods, eye contact, providing support and friendly towards children with learning disabilities.

b. Teachers are not many provide an opportunity to learn new material to children with learning disabilities

c. Teachers are not many provide a key word, repetition and academic interactions to children with learning disabilities

d. Teachers have not been much praised positive things and many criticized the negative things that the student children with learning disabilities.

Four of the above indicates that expectations of teachers to children with learning disabilities still low. Knowledge, hope and acceptance were influential factor in the provision of teaching accommodation and modification. These three things are intertwined with each other. Teacher's knowledge of children with learning disabilities can form appropriate expectations and ultimately manifested at the reception in daily interactions in the classroom. The same thing also expressed by Grover and Hendricks (2000) that the provision of teaching accommodation and modification are based on the ability of teachers to understand and recognize the needs of students. In fact, teachers are expected to receive, adapt and develop strategies in accordance with the conditions and needs of children with learning disabilities.

3.1.2 Exploring the Implementation of Teaching Accommodation and Modification for Children with Learning Disabilities Nowadays

Based on the result of interview to the principals and the teachers, there is the potential that children with learning difficulties and their prevalence is high enough to make the position of the teacher as the main actor and the most decisive classroom situation into focus in this study. Teachers still not accepted, adapted and developed yet strategies appropriate to the conditions and needs of the children with learning disabilities in learning. It became a strong foundation in the early efforts to model implementation of this teaching accommodations and modifications. This model seeks to meet the needs of teachers' knowledge, acceptance and teaching skills of children with specific learning difficulties or learning disabilities without sacrificing other children.

\subsubsection{The Result of Collecting Information and Suggestion from the Bureaucrat, Practitioners and the Experts}

The information and suggestion from the bureaucrat, practitioners and the experts as follows:

Handling children with learning disabilities is still not implemented adequately, meaning not provide a good solution to make teaching accommodations and modification for children with learning disabilities.

Perceptions and expectations of teachers to the problems of handling children with learning disabilities still tends to be negative, hence the need for guidelines on the application of teaching accommodation and modification for children with learning disabilities.

Model teaching accommodation and modification that has been tested, could be implemented as a model further through the involvement of school more and increase the participants in order to obtain more models effective.

Related to the requirement of teaching accommodations and modification for the children with learning disabilities at school should coordinate together with Educational Official local office. 


\subsection{Training and Workshop}

Training and workshop which was applied in teaching accommodation and modification for children with learning disabilities in elementary inclusive classroom was held in Yogyakarta on July 15, 2017 for Yogyakarta Special Province; in Prembun on August 22 for Centre of Java; and in Ngawi on August 24 for East of Java, Indonesia.

Training and workshop material had used the guide book of implementation teaching accommodation and modification for children with learning disabilities in elementary school. Teaching accommodation and modification is a model that contains management class situation, the flexibility of the process and evaluation of learning. Flexibility is done in four things: (1) the provision of material and the way of teaching, (2) giving assignments and assessment, (3) the demands of time and schedules, and (4) the learning environment. Four points are supported by management that supports the academic climate situation "supportive learning environment". Climate academic support / enabling its anything related to the attitude, the behavior of the teacher and other students who demonstrate acceptance of the existence of children with learning disabilities. Acceptance of the teacher in this case is associated with positive teacher expectations against children with learning disabilities.

Procedures for application of the model of teaching accommodation and modification were divided into two sequences of implementation.

The first, made preparations to realize a conducive academic atmosphere. This is not done by the teachers adequately, it is evident that there are still teachers who leave the classroom situation that is not conducive to such a rowdy class, students do not pay attention to the teacher's explanation.

Second, the implementation of collaborative material accommodation and modification between teachers and sustainable. To realize the conducive academic atmosphere, the acceptance of the diversity of the student by the teacher an absolute must have. Therefore, teachers need to look at the needs of children with learning disabilities and have adequate knowledge. Flexibility in the four domains described as follows: (1) Materials and Teaching ways, including: (a) The use of the learning method VAKT (visual, auditory, kinesthetic, tactile); (b) The provision of more frequent during the learning process; (c) Use of tools (computers, calculators, tape recorders); (d) Use of peer tutors; (e) assurance of the child's attention to the teacher before explaining the material; (f) The repetition in explaining the material; ( $g$ ) Flexibility child out of the classroom to receive any other additional learning. (2) The assignment and assessment, consisting of: (a) writing a list of tasks for the students who cannot write; (b) Making homework somewhat different from his friends (adjustable capability); (c) Provision of tasks easier / less than other friends; (d) Question directly to students; (e) Provision easier question; (f) Provision of assistance in the task; (g) Reading matter for students who cannot read. (3) The demands of time and schedule: (a) Giving a break to rest; (b) Giving more time to do the task. (4) The learning environment, among others: (a) Provision of a separate examination for children with limited attention / easy switch; (b) The placement of a child in the front row of seats; (c) Request to parents to pay more attention to children's learning at home; (d) The placement of students in a particular group (equivalent to their ability)

Third, the application flexibility of learning that had been adapted to the needs of children with learning disabilities. Some things to note in this stage is a response to children with learning disabilities and friends / other students (verbal and non-verbal) and the smoothness of Teaching and Learning (whether learning competencies can be achieved?).

Based on the results of questionnaires, interviews and observations, the activity of which was never performed teachers among others are: (1) Providing easier question when test / quiz; (2) Provide a separate test for children with attention easily switch; (3) Allow the use of calculators, tape recorders, or computers; (4) Allowing the child out of the classroom to earn extra lessons from a special teacher.

Activity ever undertaken of teachers, among others: (1) Exploiting the potential of another from children with learning disabilities to raise the motivation to learn; (2) Create a task that can be corrected itself by children with learning disabilities; (3) Create a task with graded difficulty levels, easy, rather difficult and tough; (4) Consult with other experts;

The activities of teachers rarely performed, among others: (1) Encourage other students to help children with learning disabilities; (2) allow another student to help students who have not completed the task; (3) Placing children with learning disabilities children with learning disabilities on certain groups (the equivalent of their ability) while working on the task; (4) Using media that can be touched and touched by children.

Activities often do teachers among others are: (1) Ensure the child 's attention to the teacher before describing 
the material (2) Provide additional lessons to explain the material outside of the effective; (3) Create a task with graded difficulty levels, easy, rather difficult and tough.

Activities are always performed teachers among others are: (1) inquiry directly to the student to make sure he understands the material presented; (2) Ask parents / families pay more attention to children's learning; (3) Provide repetition in explaining the material.

Before and after training, workshop, mentoring of teaching accommodation and modification for children with learning disabilities we had provided pre-test and post-test and used the guide book of implementation teaching accommodation and modification for children with learning disabilities.

Table 1. Recapitulation score increased of training, workshop and mentoring inclusive elementary classroom of implementation teaching accommodation and modification for children with learning disabilities in Yogyakarta Special Province, Central Java (Prembun) and East Java ((Ngawi), Indonesia

\begin{tabular}{ccc}
\hline Mean/Area & Pre-test & Post-test \\
\hline Yogyakarta & 11.33 & 20.42 \\
Kebumen & 11.23 & 15.67 \\
Ngawi & 11.43 & 16.05 \\
\hline Mean & 11.33 & 17.38 \\
\hline
\end{tabular}

Training, workshop and mentoring result could increase the knowledge and experiences for inclusive elementary classroom in teaching accommodation and modification of children with learning disabilities as visualization as follows:

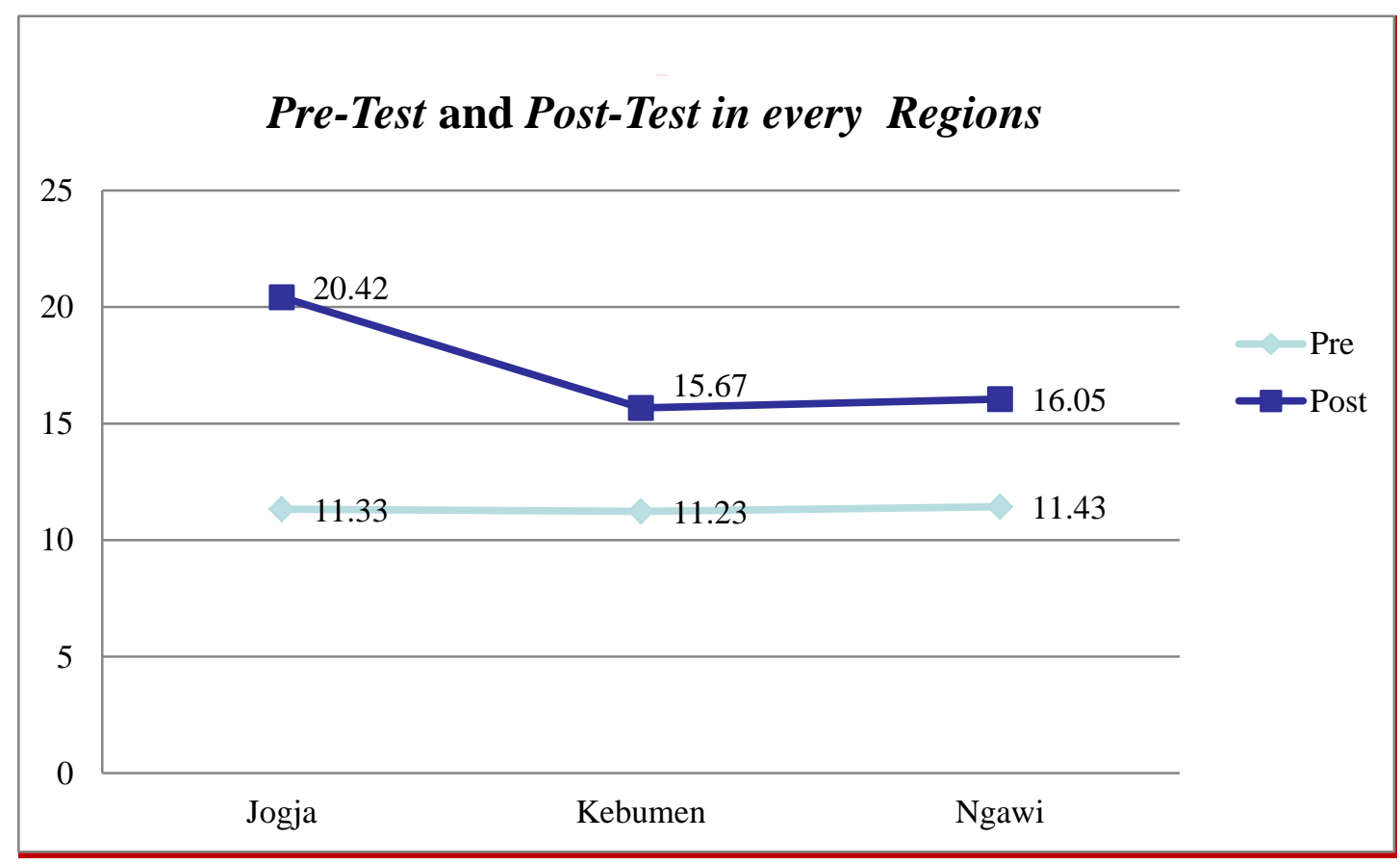

Figure 2. Pre-Test and Post-Test in every Regions

Based on the graph above, it can be seen that:

3.2.1. Average (mean) number of pre-test points for each region ie. Yogyakarta, Kebumen, and Ngawi have almost the same number of points

3.2.2. Average (mean) total number of pre-test points as a whole that is equal to 11.33

3.2.3. Average (mean) total number of post-test points as a whole that is equal to 17.38

3.2.4. Average (mean) number of post-test points for Yogyakarta region and 2 other areas of Kebumen and 
Ngawi have significant difference of about 4.6 points

3.2.5. Average (mean) total number of points of Yogyakarta region is highest among the 2 other regions which is 20.42

3.2.6. While the mean for the other two areas of Kebumen and Ngawi are only at odds of 0.4, where Ngawi is still higher than Kebumen

3.2.7. Yogyakarta region experienced the highest increase, with the mean number of pre-test points of 11.33 and the mean number of post-test points of 20.42 then an increase of about $80 \%$

3.2.8. For the Kebumen and Ngawi areas, there is an approximately $40 \%$ increase in the number of pre-test points to the post-test

The teachers of trainees and workshops are very excited and enthusiastic to participate in training and workshop activities. Most of them said they were very useful and wanted to follow again similar training and workshops.

\subsection{Mentoring}

Monitoring and mentoring on dissemination and implementation activities of the model and guidance book of teaching accommodation and modification for children with learning disabilities on 16th of October until 20th October 2017 in Yogyakarta Special Region, 21 until 24 October 2017 in Prembun Central of Java and 25 until 28 October 2017 in Ngawi East of Java, Indonesia. In this activity the researcher is assisted by 10 students of Special Education Study Program Special Education Department of Faculty of Education Yogyakarta State University. The results of monitoring indicated that the teachers still need mentoring in implementing teaching accommodation and modification for children with learning disabilities, than they had assisted by teachers. Students have benefited greatly in helping researchers, especially in the application of teaching accommodation for children with learning difficulties for finishing their study.

\subsection{Evaluation}

Evaluation of dissemination and implementation result of model and guidance of teaching accommodation modification for children with learning disabilities was conducted 21 - 25 September 2017. Evaluation result showed that mentoring can improve teacher skills in providing teaching accommodation and modification for children with learning disabilities. The results of the mentoring indicated that there is an increase in teachers' skills to implement teaching accommodation and modification model in the handling of children with learning disabilities. In this mentoring has also been demonstrated how to do teaching accommodation and modification for children with learning difficulties.

Models of teaching accommodation and modification effective enhance teachers' skills to handle children with learning disabilities through training and mentoring. It could be shown in the teacher's view of teaching accommodation and modification for children with learning difficulties.

\section{Discussion}

Based on result of the tests and questionnaire that the teachers answer show that most of teacher of elementary inclusive school still less of knowledge, acceptance response and skill to handle the children with learning with disabilities. This fact also similar with the finding of researcher from Chiang Mai University that most of teacher of elementary inclusive school still less of knowledge, acceptance response and skill to handle the children with learning with disabilities (Tongsookdee, 2016). Teachers still not accepted, adapted and developed yet strategies appropriate to the conditions and needs of the children with learning disabilities in learning. It became a strong foundation in the early efforts to model development of this teaching accommodations and modifications for children with learning disabilities. This model seeks to meet the needs of teachers' knowledge, acceptance and teaching skills of children with learning disabilities without sacrificing other children.

Workshop and Focus Group Discussion on compiling hypothetical model design which applied in teaching accommodation and modification program was held on 22 and 28 May 2016. The design was in the form of model and teaching accommodation and modification guide book, evaluation system and achievement indicator in the model implementation. Torey (2004) explained about the accommodation coverage which applied in the process of teaching and learning. There are some coverages of accommodation as follows: (1) Material and way of teaching; (2) Assignment and assessment in the class; (3) Time demand and scheduling; (4) Area of learning; (5) Use of special communication system. Children with learning disabilities can communicate with surroundings through language with no special specification so that the use of special language is not discussed in this research.

To achieve optimal results, then the implementation of the handling of children with learning disabilities based 
on teaching accommodations and modifications, as a model for teaching accommodation and modification of children with learning disabilities in elementary inclusive schools, required manual that can be used as a guideline in the implementation of handling children with learning disabilities. Therefore, the model and product teaching accommodation and modification of children with learning disabilities which has been tested and validate, should be implemented further.

Having held socialization on the application of teaching accommodation and modification for children with learning disabilities, elementary inclusive school teachers turned out to be able to understand and can apply the model of teaching accommodations and modifications for children with learning disabilities

\section{Conclusion}

In the third year of research it was concluded that:

1. The dissemination and implementation of teaching accommodation and modification for children with learning disabilities in elementary inclusive classroom had done in three provinces that were in Yogyakarta Special Province, Centre Java Province and East Java Province areas, Indonesia.

2. The third year of research had done dissemination and implementation through socialization, training, workshop and mentoring: (1) Handling children with learning disabilities is still not implemented adequately; (2) Perceptions and expectations of teachers to the problems of handling children with learning disabilities tends to be negative, hence the need for guidelines on the application of teaching accommodation and modification for children with learning disabilities; (3) the skills of inclusive elementary classroom teachers in handling the children with learning disabilities had increased through socialization, training, workshop and mentoring.

\section{References}

Akhyak, M. I., \& Abubakar, Y. (2013). Implementation of Teacher Pedagogy Competence to Optimizing Learners Development in Public Primary School in Indonesia. International Journal of Education and Research, 1(9).

Bear, G., Kortering, L., \& Braziel, P. (2006). School completers and noncompleters with Learning Disabilities: Similarities in Academic Achievement and Perceptions of Self and Teachers. Remedial and Special Education, Pro Quest Education Journals, 27(5), 293. https://doi.org/10.1177/07419325060270050401

Bhargava, A., \& Pathy, M. (2011). Perception of Student Teachers about teaching competence. American International Journal of Contemporary Research, 1(1), 77-81.

Cook, B. G. et al. (2000). Teacher's Attitudes toward students with disabilities their included. Exceptional Children, Pro Quest Education Journals, 67(1), 115.

Favazza, P. C., Phillipsen, L., \& Kumar, P. (2000). Measuring and Promoting Acceptance of Young Children with Disabilities. Exceptional Children, Pro Quest Education Journals, 66(4), 491. https://doi.org/10.1177/001440290006600404

Fore, R., \& Boon. (2006). Implications of Cooperative Learning and Educational Reform for Students with Mild Disabilities. Reading Improvement, Pro Quest Education Journals, 43(1), 3.

Foreman, P. (2005). Inclusion in action. Melbourne Australia: Thomson.

Forlin, C. (2001). Inclusion: Identifying potential stressors for regular class teachers. Educational Research Journal, 43(3), 235-245. https://doi.org/10.1080/00131880110081017

Glaser, R. (1977). Adaptive Education: Individual Diversity and Learning. New York, Chicago, San Francisco, Atlanta, Montreal, Toronto, London, Sydney, Dallas: Holt Rinehart and Winston.

Hallahan, D. P., \& Kauffman, J. M. (2003). Exceptional Learner: Introduction to Special Education (9th ed.). Boston: Allyn and Bacon.

Hallahan, D. P., Kauffman, J. M., \& Llyod, J. W. (1999). Introduction to learning disabilities (2nd ed.). Boston: Allyn \& Bacon.

.(2011). Handbook of Special Education. New York: Roudledge.

Harwell, J. M. (2001). Complete Learning Disabilities Handbook: Ready - to- Use Strategies \& Activities for Teaching Students with Learning Disabilities (2nd ed.). USA: A Wiley Imprint

Lackaye, T., \& Margalit, M. (2006). Comparison of Achievement, Effort, and Self-Perceptions among Students with Learning Disabilities and their peers from different achievement groups. Journal of LD, 7(10), 206. https://doi.org/10.1177/00222194060390050501 
Lerner, J., \& Kline, F. (2006). Learning Disabilities and Related Disorders: Characteristics and Learning Strategies (10th ed.). USA: Houghton Mifflin Company.

Liakoupoulu, M. (2011). The Professional Competence of Teachers: Which qualities, attitudes, skills and knowledge contribute to a teacher's effectiveness. International Journal of Humanities and Social Science, l(21), 66.

Lopes, J. A. et al. (2004). Teachers' Perception About Teaching Problem Students in Regular Classrooms. Education \& Treatment of Children. Pro Quest Education Journals, 27(4), 394.

Maag, J., \& Reid, R. (2006). Depression among Students with Learning Disabilities: Assessing the Risk. Journal of Learning Disabilities, 39(1), 3. https://doi.org/10.1177/00222194060390010201

Parker, B. (2006). Instructional Adaptations for Students with Learning Disabilities: An Action Research Project. Intervention in School and Clinic, 42(1), 56. https://doi.org/10.1177/10534512060420011101

Pujaningsih, et al. (2002). Guidance 'Smart Plus' to deal with specific learning disabilities in children Berbah District Sleman (Research Report Student Creativity Program/PKM, Jakarta, Higher Education).

(2007). Children's Services Education learning disabilities in elementary school through Accommodation Learning (Thesis, Bandung, UPI).

Sari Rudiyati, Mumpuniarti, \& Pujaningsih. (2015). Elementary school teachers' competence in accommodating and modifying learning process of student with learning disabilities in inclusive classroom. Proceeding 2nd International Conference on Current Issues in Education (ICCIE), Yogyakarta, Indonesia, ISSN: 2460-718.

Smith, D. (1998). Inclusion Schools for All Students. USA: Wadworth Publishing Company.

Vaidya, W., \& Zaslavsky. (2000). Inclusion Classrooms: Knowledge versus Pedagogy. Teacher education reform effort for. Pro Quest Journals, 121(1), 145.

Westerlund, D. (2006). Effect of Peer Mentors on Work - Related Performance of Adolescents with Behavioral and/or Learning Disabilities. Journal of Positive Behavior Interventions; Pro quest Education Journals, 8(4), 244. https://doi.org/10.1177/10983007060080040601

Yuen, M., Westwood, P., \& Wong, G. (2004). Meeting the needs of Students with Specific Learning Difficulties in the Mainstream Education System. The International Journal of Special Education, 20(1), 278.

\section{Copyrights}

Copyright for this article is retained by the author(s), with first publication rights granted to the journal.

This is an open-access article distributed under the terms and conditions of the Creative Commons Attribution license (http://creativecommons.org/licenses/by/4.0/). 